\title{
Dermanyssus gallinae in layer farms in Kosovo: A high risk for Salmonella prevalence
}

\author{
Afrim Hamidi ${ }^{*}$, Kurtesh Sherifi ${ }^{1}$, Skender Muji ${ }^{1}$, Behlul Behluli ${ }^{1}$, Fatgzim Latifi ${ }^{1}$, Avni Robaj ${ }^{1}$, Rezart Postoli ${ }^{2}$, \\ Claudia Hess ${ }^{3}$, Michael Hess ${ }^{3}$ and Olivier Sparagano ${ }^{4}$
}

\begin{abstract}
Background: The poultry red mite (PRM), Dermanyssus gallinae (D.g.) is a serious ectoparasitic pest of poultry and potential pathogen vector. The prevalence of D. $g$. and the prevalence of Salmonella spp. within mites on infested laying poultry farms were investigated in Kosovo.

Findings: In total, 14 populated layer farms located in the Southern Kosovo were assessed for D. g. presence. Another two farms in this region were investigated 6 months after depopulation. Investigated flocks were all maintained in cages, a common housing system in Kosovo. A total of eight farms were found to be infested with D. g. (50\%) at varying levels, including the two depopulated farms. The detection of Salmonella spp. from D. g. was carried out using PCR. Out of the eight layer farms infested with D. g., Salmonella spp. was present in mites on three farms (37.5\%).
\end{abstract}

Conclusions: This study confirms the high prevalence of D. g. in layer flocks in Kosovo and demonstrates the link between this mite and the presence of Salmonella spp. on infested farms.

\section{Background}

The PRM D. g. is one of the most serious and widespread pests of poultry production. It is a worldwide ectoparasitic pest [1], showing genetic variation between the UK, France and Italy [2]. D. g. hides in cracks and crevices in poultry units and infests the birds only briefly for blood meals, mainly at night [3]. This haematophagous mite feeds rapidly from its host (in comparison with ticks for example) and can survive several months without a blood-meal. The mites enter poultry houses through open wall fans, wall inlets and air chimneys [4] or are brought by staff, bird cages, crates or wild birds. In recent years, the frequency of $D . g$. infestations in laying hens has increased in Europe, as has its pest status.

$D$. g. can have a significant economic impact in poultry production by causing a reduction in egg production, loss in body weight of birds, and a reduction of welfare of laying hens [5]. D. g. may also cause dermatitis in humans $[6,7]$. Infestation with $D . g$. can cause irritation and restlessness in affected hens and can even result in the death of birds [8]. It is reported that the death rate among the

\footnotetext{
* Correspondence: afrimhamidi@hotmail.com

${ }^{1}$ Faculty of Agriculture and Veterinary, University of Prishtina, Kosovo

Full list of author information is available at the end of the article
}

hens can rise from 1 to $4 \%$, with a reduction in laying performance of up to $10 \%$, as a result of infestation. Downgrading of egg quality in poultry affected by $D . g$. has also been observed $[9,10]$.

In addition to causing 'direct' losses in poultry production systems, $D . g$. has also been described as a potential vector of several bacteria and viruses of concern to poultry, among them several food borne pathogens [11-14].

In order to assess levels of $D$. $g$. infestation on farms different mite traps have been evaluated and used as indicators to inform control decisions $[15,16]$. Effective options available for control of $D$. $g$. are limited [17]. The use of inadequate, ineffective, or even illegal chemicals have been responsible for increases in infestation rates due to the spread of acaricide resistance now common in many countries [1]. Nevertheless, some products are still being developed and used with some success. For example, [18] found that phoxim $50 \%$ is an effective acaricide against D. g. with [19] showing the same to be true of spinosad.

$D . g$. is widespread among farms in Kosovo and might cause high economic losses within the national poultry industry. 


\section{Infestation rate}

Fourteen populated layer farms $(6,000$ - 20,000 birds, from 6 to 12 months of age) and two de-populated farms located in Southern Kosovo were investigated for the prevalence of $D . g$. (Table 1 ). The 16 farms all had generally poor biosecurity measures, such as lack of traffic control and personal hygiene.

$D$. $g$. prevalence was determined using cardboard traps, which were placed into cages, but out of reach of the birds. Traps were left in place for $48 \mathrm{~h}$, after which they were removed and evaluated for the presence of D.g. Ten cardboard traps were used at each farm and combined as a single pooled sample on the day of their collection. Traps, which were positive for $D$. $g$., were frozen at $-20^{\circ} \mathrm{C}$ to kill any mites present. Mite numbers were assessed and the number of individuals (adults, larvae and nymphs) per trap were estimated to the nearest 50 .

\section{Incidence of Salmonella spp}

Pooled samples of $D . g$. adults, nymphs and larvae (of between 50 and 100 mites) from each infested farm ( $\mathrm{n}=$ 8 ), were selected in the laboratory and placed into plastic tubes and stored at $-20^{\circ} \mathrm{C}$. All samples $(\mathrm{n}=80)$ of D. $g$. were examined for the presence of Salmonella using PCR.

Bacterial DNA was extracted using Dneasy Tissue Kit (QIAGEN) according to the manufacturer's instructions. Extracted DNA ( $25 \mu \mathrm{l} /$ pooled mite sample) was stored at $-20^{\circ} \mathrm{C}$. The PCR reaction mixture $(25 \mu \mathrm{l})$ contained: $5 \mu \mathrm{l}$ DNA sample, $14.05 \mu \mathrm{l}$ distilled $\mathrm{H}_{2} \mathrm{O}, 2.5 \mu \mathrm{l}$ 10xPCR Buffer, $0.75 \mu \mathrm{l} \mathrm{MgCl} 2$ (50 mM), $0.5 \mu \mathrm{ldNTP}(10 \mathrm{mM})$, $1 \mu \mathrm{M}$ of each primer and $1.25 \mathrm{U}$ Taq DNA Polymerase. DNA was amplified according to [20]. The 16S rDNA primer sequences were: (forward)5'-TGT TGT GGT TAA TAA CCG CA-3' and (reverse)5'-CAC AAA TCC ATC TCT GGA-3'. PCR amplifications were performed in thermal cycler with a cycling program consisting of a 10 min denaturation step $94 \mathrm{C}$, followed by 35 cycles of denaturation $\left(1 \mathrm{~min}, 94^{\circ} \mathrm{C}\right)$, annealing $\left(45 \mathrm{~s}, 55^{\circ} \mathrm{C}\right)$ and extention $\left(1 \mathrm{~min} 30 \mathrm{~s}, 72^{\circ} \mathrm{C}\right)$ and final extention step of $10 \mathrm{~min}$ at $72^{\circ} \mathrm{C}$ [21]. After 35 cycles the amplification product was expected to be 574 base pairs.
Amplification products, including their size, were determined by electrophoresis using $2 \%$ agarose gels.

\section{Results and discussion}

In total 8 out of 16 farms (50\%) were infested with D. $g$. to varying degrees, where mites were present in both populated and unpopulated units. Out of the eight infested farms, pooled mite samples from three premises were positive for the presence of Salmonella spp. (37.5\%). In two cases Salmonella was found in mites 6 months after the removal of layers (Farms 1 and 8). The other Salmonella-positive case was from mites trapped in a populated unit (Farm 2). Results are shown in Table 1.

$D$. g. represents a major problem for the layer industry in Kosovo and across much of the globe. Data from the present study showed that $50 \%$ of Kosovan cage rearing systems were infested with $D$. $g$., which is comparable to prevalence figures in other countries with free range rearing systems, e.g. France (56\%), UK (60\%), and Denmark (68\%) [1]. A high Salmonella spp. prevalence on infested farms was also observed, which demonstrates that D. g. may at least carry this pathogen potentially serving as vector for its spread in poultry. Such a vectorial role has already been observed under laboratory conditions [22].

As mites tested positive for Salmonella spp. in depopulated units, the role that $D . g$. can play in between-flock transmission of pathogens was also demonstrated by the present study. Salmonella was found within D. g., 6 months after the removal of birds from the infested farm. This further suggests that transovarial transmission of Salmonella by $D . g$. is a possibility considering that mites do not survive for so long they must have passed the infection to their offspring. These same results show that $D$. g. can survive long periods of fasting, suggesting that these mites may be capable of pathogen transmission between flocks. Finally, where Salmonella was found in mites present on a populated farm, no signs of clinical Salmonellosis were observed in the birds. This could pose a risk to public health through Salmonella-positive mites being squashed on eggs or when such mites would infect birds.

Table 1 Data on D. g. samples from poultry farms in Kosovo

\begin{tabular}{|c|c|c|c|c|c|c|c|c|}
\hline Farm & 1 & 2 & 3 & 4 & 5 & 6 & 7 & 8 \\
\hline nr. of samples & 10 & 10 & 10 & 10 & 10 & 10 & 10 & 10 \\
\hline nr. of PRM/sample & 50 & $50-100$ & 100 & 50 & 50 & 50 & $50-100$ & $50-100$ \\
\hline layers on the farm & No & Yes & Yes & Yes & Yes & Yes & Yes & No \\
\hline nr. of layers on the farm & $0^{*}$ & 6,000 & 12,000 & 15,000 & 20,000 & 18,000 & 16,000 & 0 \\
\hline Salmonella PCR & + & + & - & - & - & - & - & + \\
\hline
\end{tabular}

*Depopulated more than 6 months before sampling 
The transfer of $D . g$. in Kosovo seems to occur via egg boxes which are exchanged at supermarkets, originating from different egg supply companies. In general all farms infested with $D . g$. in the present study demonstrated poor biosecurity measures. The emerging potential role of $D . g$. as a vector for Salmonella spp. supported by the results presented in this paper it should encourage the poultry industry to initiate strict biosecurity programs to control both D. g. and any pathogens it may foster, carry or transmit. Assuming that these results are not specific to Kosovo, they could explain why salmonellosis outbreaks are still observed in other countries, such as the UK. Although all birds are vaccinated against Salmonella the prevalence of $D$. $g$. is very high in the UK, which could explain why Salmonella transmission can overcome the vaccination effect as different serovars exist.

\section{List of Abbreviations}

D.g.: Dermanyssus gallinae; PRM: poultry red mite.

\section{Acknowledgements and Funding}

We thank the ASSO (Austrian Scientific Support Office) and Austrian Federal Ministry for Education for funding of this scientific activity.

\section{Author details}

${ }^{1}$ Faculty of Agriculture and Veterinary, University of Prishtina, Kosovo.

${ }^{2}$ Faculty of Veterinary Medicine, Tirana, Albania. ${ }^{3} \mathrm{Clinic}$ for Poultry, Fish and Reptiles, Veterinary Medical University Vienna, Austria. ${ }^{4}$ Northumbria University, School of Life Sciences, Newcastle upon Tyne, UK.

\section{Authors' contributions}

AH worked on study design, sampling, data analysis and drafting the paper. $\mathrm{KS}$ participated in sampling, carried analysis together with $\mathrm{CH}$ at the clinic of Poultry, Reptiles and Fishes at the Veterinary Medical University in Vienna. $\mathrm{MH}$ worked on study design, data analysis and drafting the paper. SM, BB, $F L, A R$ and RP participated in sampling of D. g. OS worked on the data analysis and drafted the paper with AH. All authors read and approved the final version of the manuscript.

\section{Competing interests}

The authors declare that they have no competing interests.

Received: 2 June 2011 Accepted: 15 July 2011 Published: 15 July 2011

\section{References}

1. Sparagano O, Pavliçeviç A, Murano T, Camarda A, Sahibi H, Kilpinen O, Mul M, van Emous R, le Bouquin S, Hoel K, Cafiero MA: Prevalence and key figures for the poultry red mite Dermanyssus gallinae infections in poultry farm systems. Exp Appl Acarol 2009, 48:3-10.

2. Marangi M, Cafiero MA, Capelli G, Camarda A, Sparagano OAE, Giangaspero A: Evaluation of the poultry red mite, Dermanyssus gallinae (Acari: Dermanyssidae) susceptibility to some acaricides in field populations from Italy. Exp Appl Acarol 2009, 48:11-18.

3. Fiddes MD, Le Gresley S, Parsons DG, Epe C, Coles GC, Stafford KA: Prevalence of the poultry red mite (Dermanyssus gallinae) in England. Vet Record 2005, 157:233-235.

4. Meyer-Kühling B, Heine J, Müller-Lindloff J, Pfister K: Epidemiology of Dermanyssus gallinae and acaricidal efficacy of Phoxim $50 \%$ in alternative housing systems during the laying period of hens. Parasitol Res 2007, 101:S1-S12.

5. Chauve C: The poultry red mite Dermanyssus gallinae (De Geer, 1778): current situation and future prospects for control. Vet Parasitol 1998, 79:239-245.
6. Cafiero MA, Camarda A, Circella E: Pseudoscabies caused by Dermanyssus gallinae in Italian city dwellers: a new setting for an old dermatitis. $J$ European Acad Dermatol Venerol 2008, 22:1382-1383.

7. Cafiero MA, Camarda A, Circella E, Galante D, Lomuto M: An urban outbreak of red mite dermatitis in Italy. Internat J Dermatol 2009, 48:1119-1121.

8. Eckert J, Friedhoff KT, Zahner H, Deplazes P: Lehrbuch der Parasitologie für die Tiermedizin. Enke Verlag, Stuttgart; 2005, 369-371.

9. Kirkwood AC: Anaemia in poultry infested with the red mite Dermanyssus gallinae. Vet Records 1967, 80:514-516.

10. Van Emous RA, Fiks-Van Niekerk TGCM, Mul MF: $€ 11$ million damage for the sector: enquiry into the cost of mites to the poultry industry. De pluimveehouderij 2006, 35:8-9.

11. Chirico J, Eriksson H, Fossum O, Jansson D: The poultry Red Mite, Dermanyssus gallinae, a potential vector of Erysipelothrix rhusiopathiae causing erysipelas in hens. Med Vet Entomol 2003, 17:232-234.

12. De Luna CJ, Arkle S, Harrington D, George D, Guy J, Sparagano OAE: The poultry red mite (Dermanyssus gallinae) as a potential carrier of vectorborne diseases. Ann New-York Acad Sc 2008, 1149:255-258.

13. Valiente Moro C, De Luna CJ, Tod A, Guy JH, Sparagano OAE, Zenner L: The poultry red mite (Dermanyssus gallinae): a potential vector of pathogenic agents. Exp Appl Acarol 2009, 48:93-104.

14. Valiente-Moro C, Chauve C, Zenner L: Vectorial role of some dermanyssoid mites (Acari, Mesostigmata, Dermanyssoidea). Parasite 2005, 12:99-109.

15. Nordenfors H, Chirico J: Evaluation of a sampling trap for Dermanyssus gallinae. J Vet Entomol 2001, 94:1617-1621.

16. Lundh J, Wiktelius D, Chirico J: Azadirachtin-impregnated traps for the control of Dermanyssus gallinae. Vet Parasitol 2005, 130:337-342.

17. Siegmann O, Neumann U: Lehrbuch Kompendium der Geflügelkrankheiten. Schlüttersche, Hannover, 6, aktualisierte erweiterte Auflage; 2005, 314-316.

18. Meyer-Kühling B, Pfister K, Müller-Lindloff J, Heine J: Field efficacy of phoxim 50\% (ByeMite) against the poultry red mite Dermanyssus gallinae in battery cages stocked with laying hens. Vet Parasitol 2007, 147:289-296.

19. George D, Guy J, Appleby WGC, Knox A, Shiel RS: In vitro and in vivo acaricidal activity and residual toxicity of spinosad to the poultry red mite, Dermanyssus gallinae. Vet Parasitol 2010, 173:307-3161.

20. Lin C, Tsen H: Use of two 16S DNA targeted oligonucleotides as PCR primers for the specific detection of Salmonella in foods. J Appl Bacteriol 1996, 80:659-666.

21. Desloire S, Valiente-Moro C, Chauve C, Zenner L: Comparison of four methods of extracting DNA from D. gallinae (Acari: Dermanyssidae). Vet Res 2006, 37:725-732.

22. Valiente Moro C, Chauve C, Zenner L: Experimental infection of Salmonella enteritidis by the poultry red mite, Dermanyssus gallinae. Vet Parasitol 2007, 146:329-336.

doi:10.1186/1756-3305-4-136

Cite this article as: Hamidi et al:: Dermanyssus gallinae in layer farms in Kosovo: A high risk for Salmonella prevalence. Parasites \& Vectors 2011 4:136.

\section{Submit your next manuscript to BioMed Central and take full advantage of:}

- Convenient online submission

- Thorough peer review

- No space constraints or color figure charges

- Immediate publication on acceptance

- Inclusion in PubMed, CAS, Scopus and Google Scholar

- Research which is freely available for redistribution 